\title{
ARE THERE LIMITS FOR TOURISM DEVELOPMENT IN MEĐUGORJE?
}

\author{
Snježana Musa ${ }^{52}$ \\ Željka Šiljković s3 $^{33}$ \\ Amra Banda ${ }^{54}$
}

\begin{abstract}
Međugorje is the biggest pilgrimage center of Southeastern Europe. It is located in the southern part of Bosnia and Herzegovina, in western Herzegovina. Before the apparitions in Međugorje, it was a karst agricultural region in which its population mostly lived off agriculture, namely cultivating tobacco and grapes. Despite the fact that the official Catholic church does not recognise Međugorje as the place of the Marian apparition, that has never prevented religious people from all over the world to visit. Since 1981, when, according to the belief of the local people, the Virgin Mary appeared, until 2016, this little Herzegovinian place was visited by more than 30 million pilgrims. More than $80 \%$ of pilgrims are foreigners (Italians, Czechs, Germans, Koreans, Lebanese, Poles, Ircs and others), so Međugorje has become an international marian shrine. The Appearance of Our Lady of Međugorje as a specific event has had multiple consequences for the development of this poor peripheral Herzegovinian village: development of pilgrim tourism, landscape transformation, development of the tertiary sector, change of socio-economic structure of the population and population growth. The village greatly expanded in buildings and the landscape is transformed beyond recognition. Nowadays, tourism is the dominating activity - agriculture is becoming rare, apart from viticulture and, only recently, growing olives. This paper analyzes characteristics of tourism and urban development of Međugorje that generated a series of negative consequences, since it completely ignored the need for destination management and spatial planning.
\end{abstract}

Keywords: Međugorje, religious tourism, tourism development, urban chaos

\section{INTRODUCTION}

From prehistoric times people had proclaimed certain places as holy, where they went to seek help and mercy from their gods and saints (Leutar, et.al., 2007). These pilgrimages were usually small villages, like the Catholic Fatima, Lourdes, Nazareth and Marija Bistrica.

With time, these religious places and shrines became tourist attractions, actually destinations that annually got tens of thousands tourists who were pilgrims, "classic" tourists or merely just inquisitive visitors.

First pilgrims, also being tourists ${ }^{55}$, were most probably people travelling to places considered as shrines. With time, those religious places and shrines became tourist

\footnotetext{
${ }^{52}$ Full Professor, University of Mostar, snjezamusa@hotmail.com

${ }^{53}$ Full Professor, University of Zadar

${ }^{54}$ Senior Teaching Assistant, Department of Geography, Faculty of Science, University of Sarajevo
} 
attractions, actually destinations that annually got tens of thousands tourists who were pilgrims, classic tourists or merely just inquisitive visitors. In this manner those shrines become important factors in the development of modern tourism (Collins, 2012; Krešić et.al, 2012). Considering the most frequent locations of shrines, religious attractions are an important factor in initiating rural tourism. In peripheral rural regions religion is the mean to promote local industry and a way to regenerate rural areas.

As a consequence of religious pilgrimage tourism, the economy in those areas starts to diversify (Pourtaheri et. al., 2012). Traditional activities - such as land management and animal husbandry - become less important source of income while the population turns to catering and tourism, i.e. the tertiary sector. The peripheral area is thus economically activated which means that pilgrim tourism opens up new dimensions in development of the entire community: economic, social, and physical (Figure 1).

The arrival of tourists to a shrine brings forth the need for accommodation; beds and food as well as entertainment in their leisure time. Thus the need to build motels, hotels, guest houses, restaurants, museums and other facilities arises. Revenue brought about by such tourism is not limited to the individual, but becomes the income of the whole community, interwoven in the management of the steady supply chain. Tourism thus enables the creation of new jobs, particularly those for local residents.

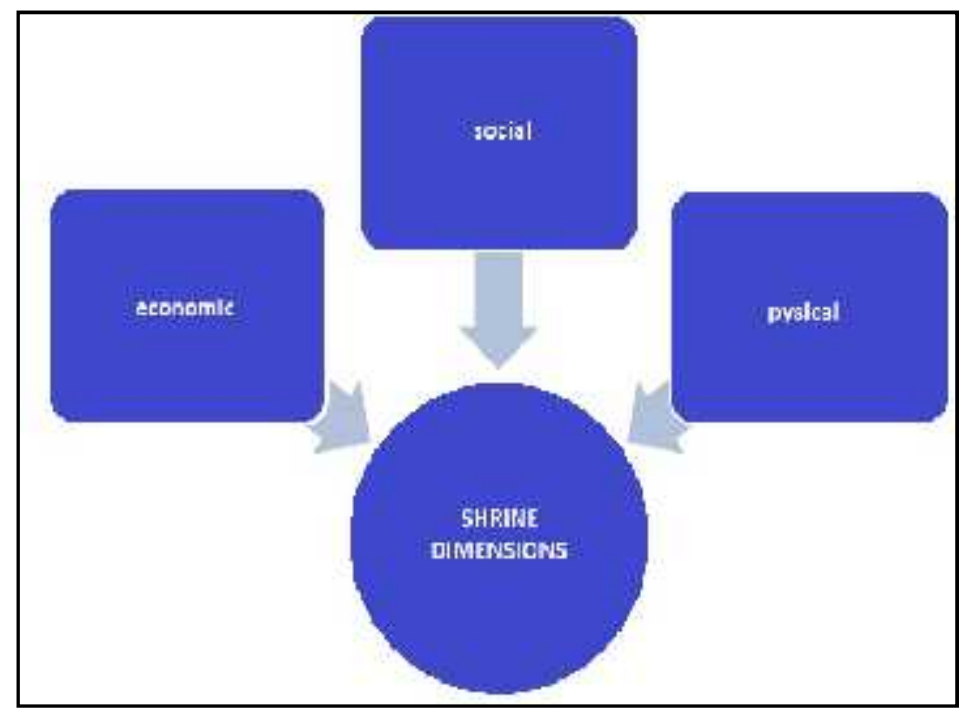

Figure 1: Dimensions of the development and transformation of the shrine Source: Pourtaher et.al., 2012.

\footnotetext{
55 This happened in the $8^{\text {th }}$ century when organised travelling took place in France where the nobility travelled to Palestine and other countries in the Near East. Later those journeys became medieval historical itineraries, the oldest being "Way of the roses" or "Abbot Daniel to the Holy Land" created in the $12^{\text {th }}$ century. The manuscript was published in 1895 in London as an illustrated guide "The Pilgrimage of the Russian Abbot Daniel to the Holy Land, 1106-1107 A.D." by C.W. Wilson.
} 
Tourist are encouraged to spend, among other places, in shopping malls and restaurants; they enable reopening of forgotten crafts, artefacts that will make pilgrims reminiscent of the visited shrines, the development of gastronomy, etc. In such places, previously extremely cheap, almost worthless land gets expensive.

The social dimension of the pilgrim society can be seen not only in the connection between the local population and the pilgrims, in the rise of the social status of the local population and reduced emigration, but also in the influx of a new population that permanently inhabits the region.

Pilgrimage shrines are universally considered to be safe areas where fear of getting mugged or robbed is unnecessary, yet such beliefs are not always justified. Shrines are places of false begging, crime and fraud.

Increased economic power of the local population leads to an increase in the quality of life in households and the community in general: there is investing in construction infrastructure (water supply, power supply network, sewage) and high-quality traffic facilities are built - all of these elements become physically visible dimension of the site of the pilgrimage (Pourtaher, et.al., 2012).

This well-established and adopted matrix of the development of the tourist centre is not applicable to every tourist destination, particularly not to the fourth in Europe Marian shrine - Međugorje.

\section{CASE STUDY - MEĐUGORJE}

It can most certainly be concluded that one of the most famous and most visited shrines in the Christian world is the Marian shrine of Međugorje, in the southern part of Bosnia and Herzegovina, in western Herzegovina. Međugorje is a world famous tourist brand with all the symptoms of anarchic development and urban chaos.

Međugorje is situated in a karst area which covers barely $5 \mathrm{~km}^{2}$. It is surrounded by a mountain ridge, to the south by Kukovac and Križevac, to the east by Gradina, none higher than $600 \mathrm{~m}$ above sea level. The Međugorje field is located approximately at 180 $\mathrm{m}$ above sea level. Along the field flows the stream Lukoč, mainly in the rainy season. Arable land, red soil or 'terra rossa' which is good for growing grapes and tobacco is located in the lowest part of the field.

Before the Marian apparition, Međugorje consisted of five villages (Šurmanci, Bijakovići, Međugorje, Miletina and Vionica) in the area of karst plateau Brotnjo. The distance from large urban centres on the Adriatic coast (160 km Split, Dubrovnik 150 $\mathrm{km}$ ), is almost the same as from the capital city of the state (Sarajevo $150 \mathrm{~km}$ ), while only $20 \mathrm{~km}$ from the regional centre of Mostar.

In such naturally poor conditions there was no potential for development and Međugorje was a poor farming region. Traditionally, the son who stayed in the village on the property inherited all the land. Female members of the family did not have that right; even when a legal system was later established in which all the children had the 
right of inheritance, it became customary law that women "donate" their share of the inheritance to their brothers. This led to fragmentation of estates which became typically ten times their length than width, and on which it became difficult to apply agricultural machinery. In the sixties of the past century, the farmers traded their hard work mostly in the vineyards with working at construction sites in Western Europe. Emigration from these regions began even earlier, and proceeded sporadically mainly into overseas countries.

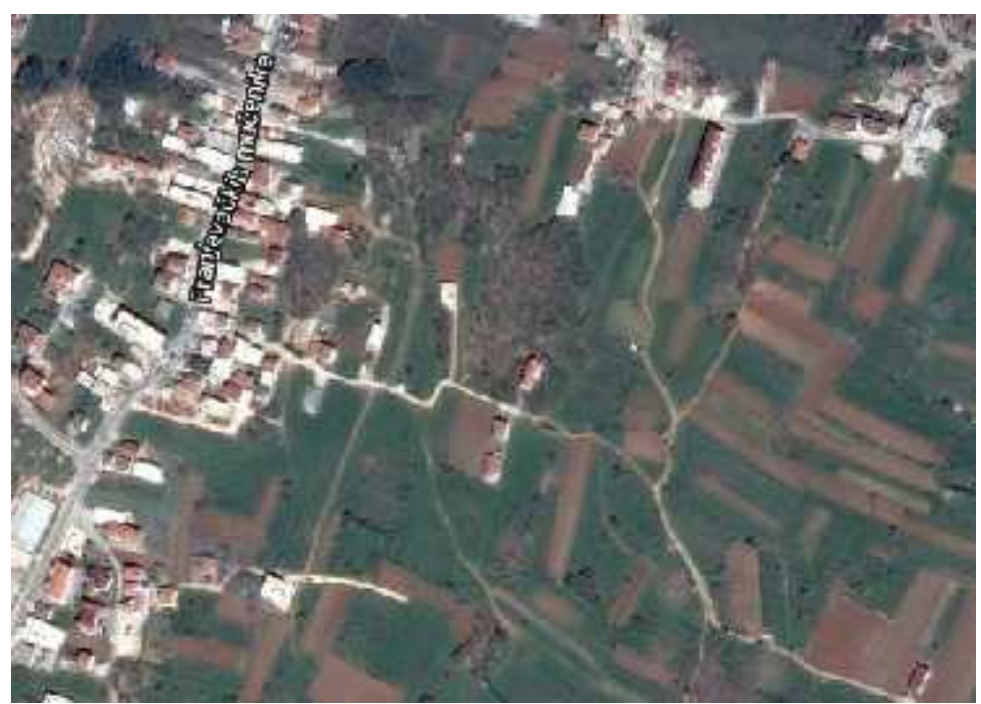

Figure 2. Fragmentation of land in Međugorje

Source: https://www.google.com/maps/@43.1888198,17.6756276,571m/data=!3m1!1e3

In such circumstances of economy and poor resources in an impoverished state, the Marian apparition was salvation. Although the government at the time opposed the expansion of the importance of the shrine, still Međugorje started getting more and more significant role as a place of pilgrimage which first started in central Bosnia, and then in Dalmatia.

\section{Economic dimensions of tourism development in Medugorje}

Before the apparitions in Međugorje, it was a karst agricultural region in which $90 \%$ of its population lived off agriculture, namely cultivating tobacco (200-300 tons per year) and grapes (400-800 tons per year) (Belaj, 2011). 


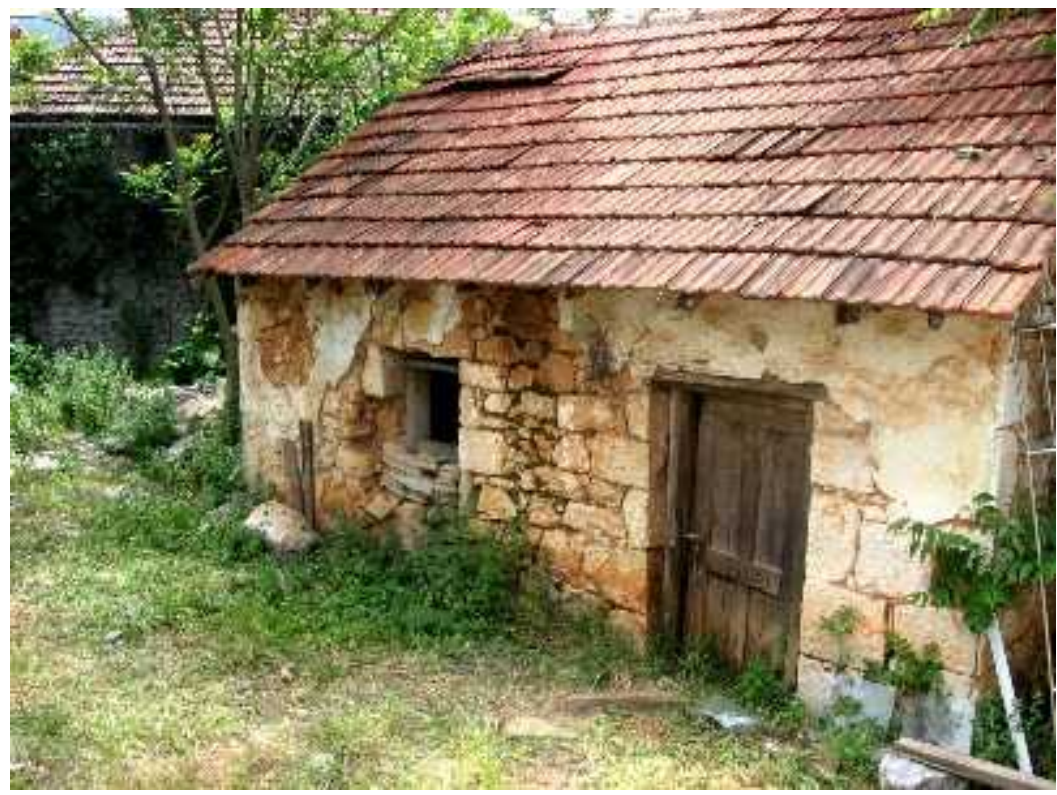

Figure 3: An old house in Bijakovići

The poor rural village with simple single story stone houses on the border of the karst field of Međugorje transforms dramatically from $24^{\text {th }}$ June 1981 when, in the village of Bijakovići, where children claimed they had seen visions of the Blessed Virgin Mary. The transformations started gradually until the end of the 1980s, i.e. until the fall of Socialist governing.

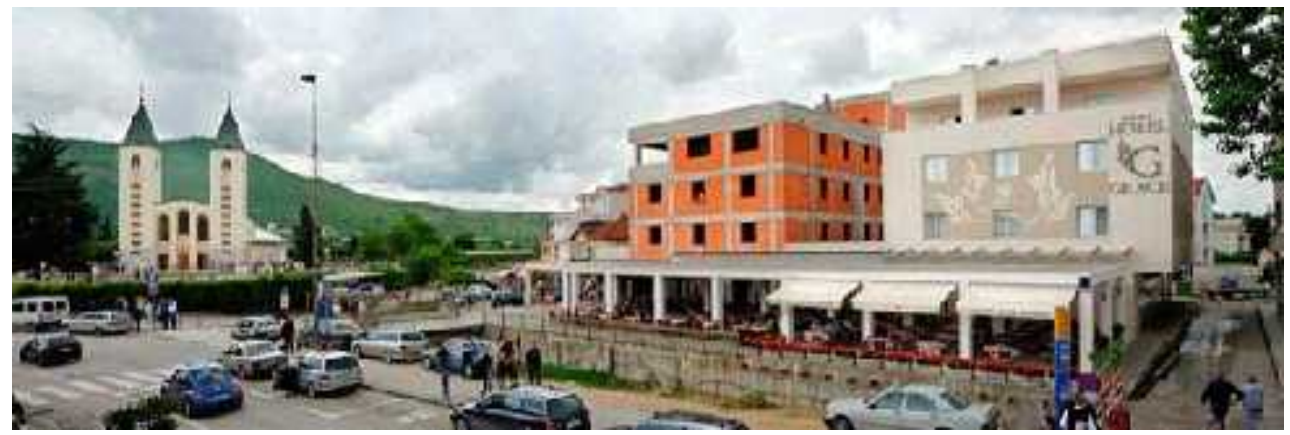

Figure 4: An example of a hotel situated 50 metres from the church, today.

In the beginning Međugorje had only a local inn. There was no accommodation in any of the villages for the pilgrims (Madžar, 2010). The first pilgrims stayed at village households without financial compensation. In the utterly agrarian area, the pilgrims visited three sites: the central St. James Church (completed in 1969), the hill Križevac 520 metres high (with its 8.56 metre tall concrete crucifix built in 1934) and the apparition site which could and can be reached by a steep, rocky path. Only one segment of the narrow village road is paved so the pilgrims use the same track as the 
buses and cars (Belaj, 2011).Agriculture, once the main activity in the area, has nowadays been almost eradicated. Up to 1980, the population was engaged in the production of tobacco, grapes and vegetables. Some fruits, like cherries and table grapes, were the earliest in the season to reach western European markets. Nowadays, tourism is the dominating activity - agriculture is becoming rare, apart from viticulture and, only recently, growing olives. Food in the shops is imported from other areas, or from Croatia and the neighbouring countries. The main source of income for $90 \%$ of households is tourism, only $10 \%$ treat tourism as an additional activity (Madžar, 2010). This fact is explicit in the change of the total number of the agricultural population in the period from 1971 to 2011 (table 3).

Table 1: Population growth in Međugorje

\begin{tabular}{|c|c|c|c|c|c|c|c|c|c|}
\hline \multirow{2}{*}{$\begin{array}{c}\text { Area } \\
\text { Year }\end{array}$} & \multicolumn{3}{|c|}{ Total population } & \multicolumn{3}{c|}{$\begin{array}{c}\text { Agricultural } \\
\text { population }\end{array}$} & \multicolumn{3}{c|}{$\begin{array}{c}\text { of agricultural } \\
\text { population }\end{array}$} \\
\cline { 2 - 9 } & $\mathbf{1 9 7 1}$ & $\mathbf{2 0 0 1}$ & $\mathbf{2 0 1 3}$ & $\mathbf{1 9 7 1}$ & $\mathbf{2 0 0 1}$ & $\mathbf{2 0 1 3}$ & $\mathbf{1 9 7 1}$ & $\mathbf{2 0 0 1}$ & $\mathbf{2 0 1 3}$ \\
\hline $\begin{array}{c}\text { Međugorje } \\
\text { with } \\
\text { Bijakovići }\end{array}$ & 2081 & 2419 & 3797 & 1311 & 97 & 35 & $63 \%$ & $4 \%$ & $1 \%$ \\
\hline
\end{tabular}

Source: The Federal Institute for statistics, 2015

Tourism brought Međugorje significant changes in the standard of living of its inhabitants. Up to 1981 most of its households had no basic infrastructure facilities.

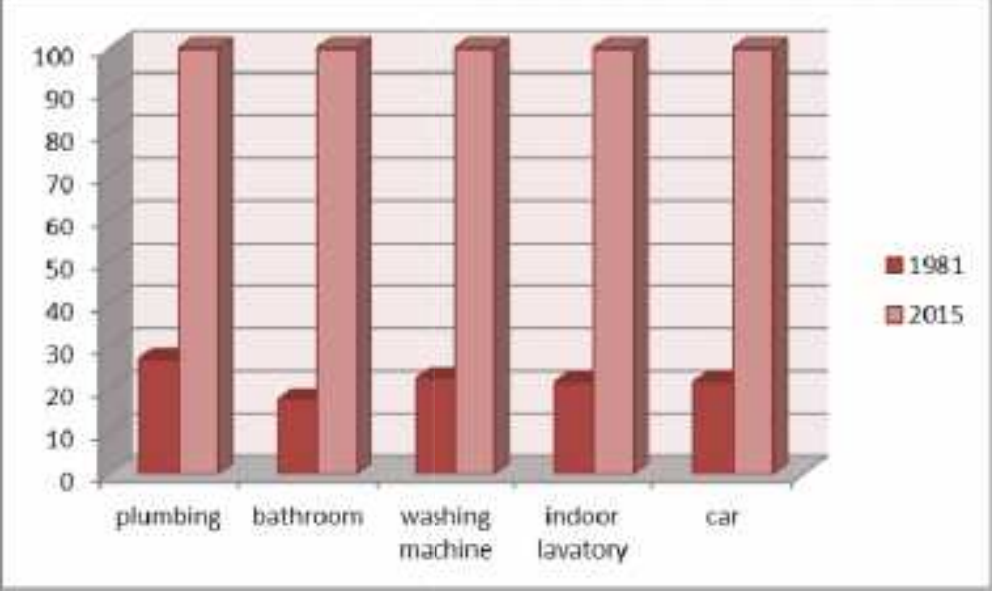

Figure 5: Infrastructural facilities in Međugorje households

Source: Madžar, 2010, research by the author, research by the authors in May 2015

Despite the fact that the official Catholic church does not recognise Međugorje as the place of the Marian apparition, that has never prevented religious people from all over the world to visit. The estimated number of visitors to Međugorje from 1981 to 2013 is 
28 million pilgrims, mostly ( $80 \%$ ) foreigners. According to the research by Culjak (2014), Međugorje earns €90 million (1981-2013 2.85 billion Euros), i.e. has 1.9 million overnight accommodations.
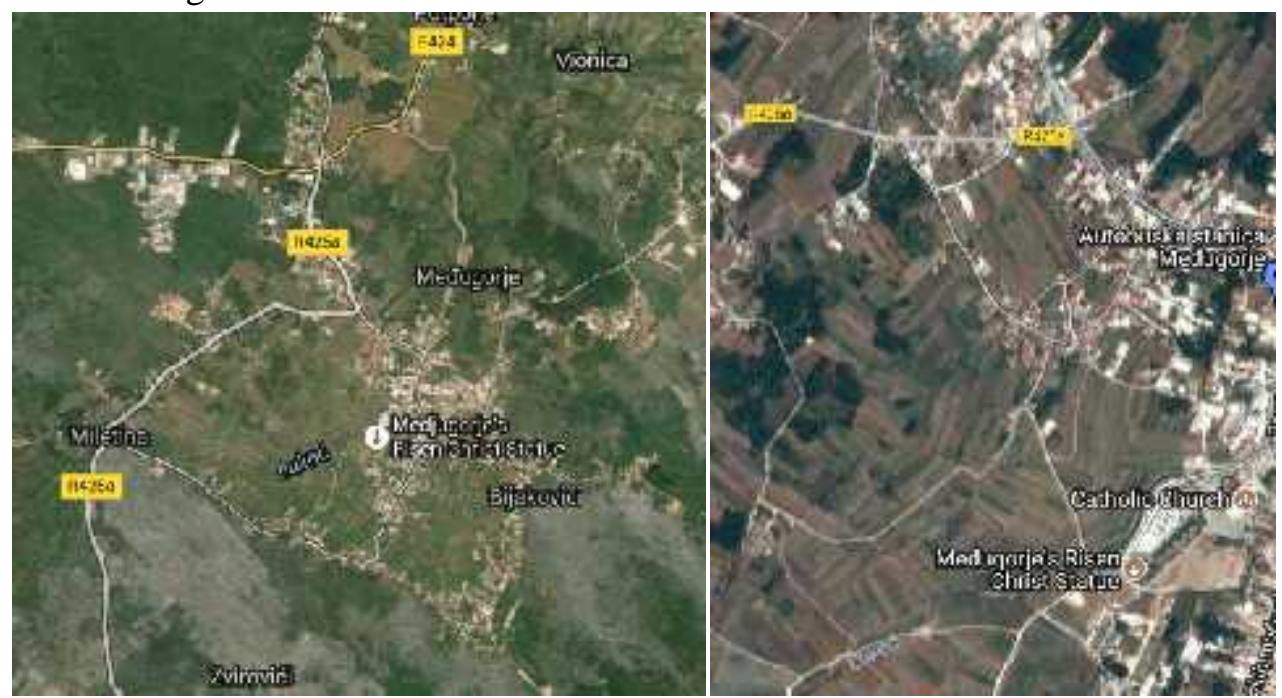

Figure 6: Area conditions and the road network in the Međugorje region Source: https://www.google.com/maps/@43.1888198,17.6756276,571m/data=!3m1!1e3

The roads through the village were not paved or even gravel but simple patches of dirt. The whole area around the church was comprised of cultivated vineyards, tobacco fields or vegetable patches. The surrounding hills were grasslands.

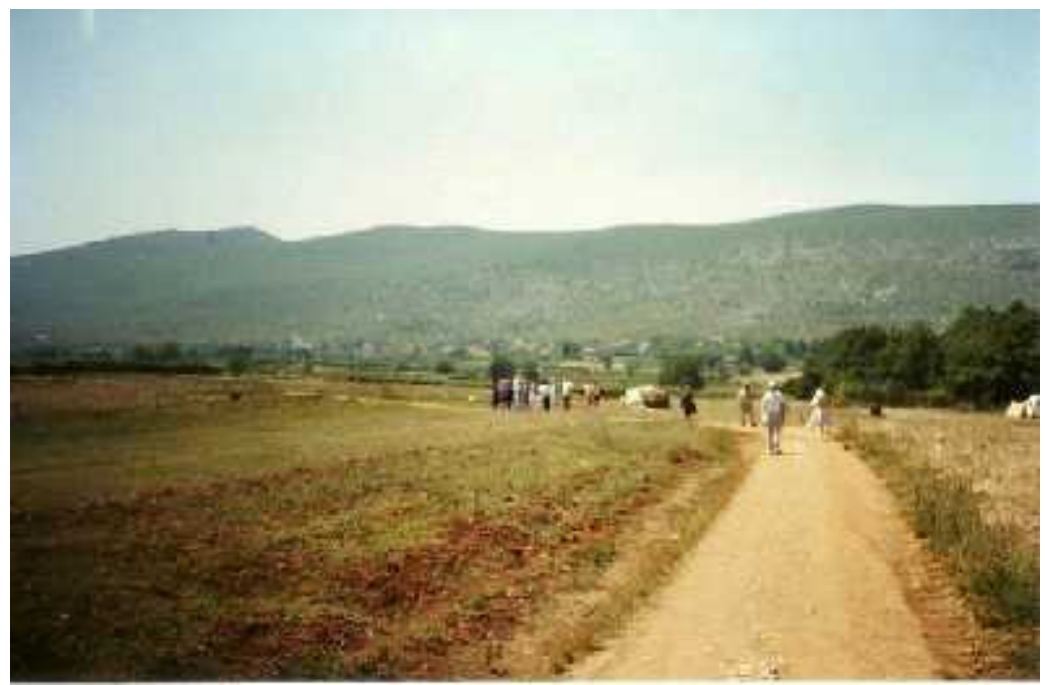

Figure 7: View of cultivated fields in 1980's 

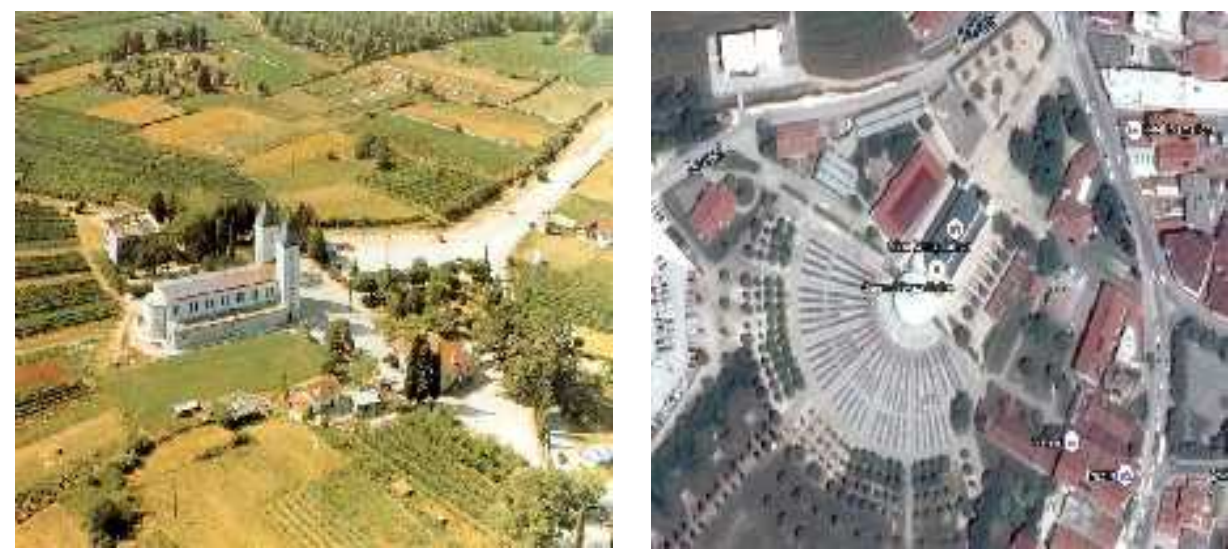

Figure 8 and 9: The agricultural landscape in the area around the church in Međugorje until 1980 (left) and the erected buildings of today (right)

Urbanization begins shortly after the Marian apparition (1983). Multi-storey houses are built for the reception of pilgrims, mostly in the vicinity of spiritual centres and along the road to the neighbouring municipal centres, Čitluk and Ljubuški. The deployment of new buildings, even their appearance, is determined by the size, shape and the ownerships of the plots of land.

\section{Physical dimensions of tourism development in Medugorje}

The social and urban dimensions of urban construction in Međugorje for the purposes of tourism has extraordinary implications for the ecological problems of the region (massing concrete, closing natural caves and pits, the lack of well-kept green areas, large asphalt areas, stamped out courtyards etc.).

The municipality of Čitluk in the time of the apparition had just adopted the spatial development plan for the next 20 years. Međugorje was and would remain to be an agricultural area. The apparition brought along pilgrims. They seek accommodation within families that receive them without financial compensation. An increasing number of visitors demands the building of accommodation facilities (table 1). The first buildings to accommodate guest are built on the existing narrow plots along narrow roads without sidewalks. Arable land disappears. The courtyards are paved as parking spaces for buses and cars. The municipality no longer has the power to control the construction. Every year the number of pilgrims increased. 
Table 2: Rise in the number of beds in Međugorje

\begin{tabular}{|c|c|c|c|c|}
\hline OBJECTS & UP TO 15 BEDS & $\mathbf{1 5 - 3 0}$ & $\mathbf{3 0 - 5 0}$ & MORE THAN 50 \\
\hline $\mathbf{1 9 8 9 .}$ & 36 & 49 & 26 & 9 \\
\hline $\mathbf{2 0 0 3 .}$ & 18 & 32 & 65 & 5 \\
\hline $\mathbf{2 0 1 5 .}$ & 10 & 25 & 52 & 31 \\
\hline
\end{tabular}

Source: Madžar (2010) and research by the author

The urban development of Međugorje generated a series of negative consequences since it completely ignored the need for management of the destination, and that led to an anarchy of urban and infrastructural development (Vukonić, 1992). After the initial domination of local pilgrims (from former Yugoslavia), and a large number of those from the United States, today the most frequent visitors come from Slovakia, the Czech Republic and Poland, followed by the Irish and Italians.

Intensive construction of residential and service facilities and hotels, apartments and guest houses used for accommodating of tourists from developed countries called for an increase categorization of hotels and guest houses, thus renovating construction work became ubiquitous. The locals claim that every five to seven years they have to renew their bathrooms, beds, kitchens, etc. which creates a huge amount of solid structure waste material which is not recycled but dumped in karst pits, natural caves and mostly illegal dumpsites.

Additional facilities, such as restaurants, cafes, shops, souvenir stands, clothing, and recreational facilities (for football, basketball, volleyball and tennis, and also swimming pools) are constantly being built. In the region of the city of Čitluk, the number of beds in accommodation units from 1980 to 2005 tripled, while naturally, more than $95 \%$ of the accommodation capacity is connected to Međugorje. It is believed that today there are approximately 50,000 beds, yet there is no official data (table 3 ).

Table 3: Number of beds in special categories of accommodation, the official data from the Federal Institute for statistics in Bosnia and Herzegovina.

\begin{tabular}{|c|c|c|c|c|c|c|c|c|}
\hline 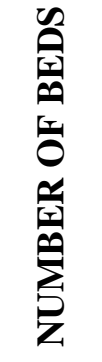 & 国 & $\stackrel{\theta}{\underline{\theta}}$ & 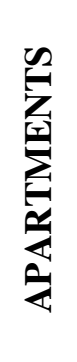 &  & $\sum_{\substack{0 \\
0}}^{\infty}$ & $\sum_{\circlearrowright}^{\circlearrowright}$ & 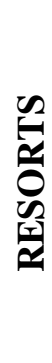 & 承 \\
\hline 1980. & 32 & 0 & 0 & 0 & 0 & 0 & 0 & 32 \\
\hline 2005. & 880 & 160 & 88 & 3960 & 880 & 120 & 0 & 6088 \\
\hline 2015. & 1026 & 180 & 115 & 4230 & 960 & 120 & 0 & 6631 \\
\hline
\end{tabular}

Source: Madžar (2010) and research by the author 
The village greatly expands in buildings and the landscape is transformed beyond recognition. Međugorje is becoming chaotic, a place of anarchy with no urban plan, no legalised objects (57\% of the buildings constructed are illegal), no sewage network, insufficient electric supply and no constructed rubbish deposits ${ }^{56}$ (Belaj, 2012).

The environmental awareness of the local population is not at a high level. There is an enormous production of communal waste, the air is polluted, and light pollution is excessive. A special problem is the closing of karst pits and natural caves which have become dumpsites. Local stream beds are often used as roads, whereas they get paved. Green areas, sometimes even vineyards, often become paved parking lots.

Such unplanned tourism produces a continued negative impact on the environment. Illegal construction sites, tax evasion, objects in a non-traditional architectural style, a cultural lack of awareness of the population are all problems which the shrine has to face. A great many vehicles - buses, vans, commercial vehicles and passenger cars have no parking spaces; the streets are narrow, clogged by vehicles and pedestrians. The biggest number of pilgrims arrive at the month of the apparitions (June), during the Feast celebrating the Assumption $\left(15^{\text {th }}\right.$ August) and to celebrate the birth of Virgin Mary ( $8^{\text {th }}$ September); yet the number of sacred days has risen to nineteen burdening the traffic more often. A big problem is to determine the number of accommodation facilities today. According to the website www.booking.com, there are 118 dwellings for the reception and accommodation of tourists, eight of which are 4-star hotels, one five-star hotel and 26 three-star hotels in Međugorje at present. All facilities are equipped with Wi-Fi, parking and restaurants, some organise transport to airports while those with higher categories have wellness and spa centres with swimming pools.

Pressure on the environment is reflected in the efforts of building proprietors to get their hotel or restaurant as close to the central premises - the church of St. James, it is thus becoming quite common that hotels are built at a distance of 100 metres or less from the church.

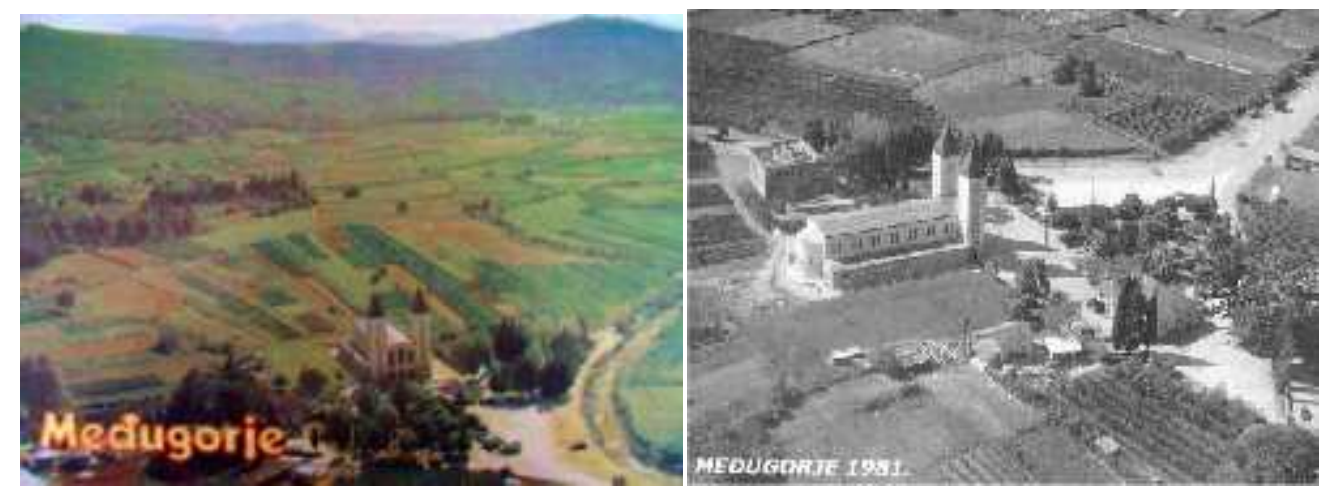

Figure 10 and 11: The premises around the church in 1981

\footnotetext{
${ }^{56}$ Entire area of Herzegovina has problems with waste managment. So far, there is only one organised landfill site on the territory of the municipality of Neum and it is overloaded as it is used also by some Croatian tourist cities from Pelješac and Korčula.
} 
The expansion of tourism has led to the settlement of newcomers from Herzegovina seeking temporary or permanent jobs in the vicinity. Inhabitants from central Bosnia also arrive; they mostly get poorly paid jobs (construction workers, maids, cleaners, etc.), while 1,500 employees - around $60 \%$ - work illegally.

Međugorje also has an influx of foreigners - the owners of numerous hotels are Irish people.

Table 4: The fluctuation of inhabitants of Međugorje from 1948 to 2013

\begin{tabular}{|l|l|l|l|l|l|l|l|}
\hline Village & $\mathbf{1 9 4 8 .}$ & $\mathbf{1 9 5 3 .}$ & $\mathbf{1 9 6 1 .}$ & $\mathbf{1 9 7 1 .}$ & $\mathbf{1 9 8 1 .}$ & $\mathbf{1 9 9 1 .}$ & $\mathbf{2 0 1 3 .}$ \\
\hline Bijakovići & 660 & 611 & 608 & 687 & 565 & 811 & 1491 \\
\hline Medugorje & 1453 & 1400 & 1263 & 1394 & 1159 & 1367 & 2306 \\
\hline Miletina & 484 & 487 & 410 & & & & 413 \\
\hline Šurmanci & 496 & 459 & 461 & & & 403 & 305 \\
\hline Vionica & 469 & 476 & 404 & 425 & 356 & 398 & 713 \\
\hline Total & 2582 & 2487 & 2275 & 2506 & 2080 & 2979 & 5228 \\
\hline
\end{tabular}

BiH Census 1948 - 2013, Federal Statistics Institute, Sarajevo, 2015

The increasing population also intensifies the demand for more building land, so arable land is converted to new purposes. The cost of land, and thus real estate, is twice higher than in the nearby villages (table 5).

Table 5: The prices of apartments and land in Međugorje and neighbouring villages

\begin{tabular}{|c|c|c|}
\hline \multirow{2}{*}{ SETTLEMENT } & \multicolumn{2}{|c|}{ PRICE PER ${ }^{2}$} \\
\cline { 2 - 3 } & LAND & APARTMENTS \\
\hline Mostar & $15 € / \mathrm{m}^{2}$ & $800-1000 € / \mathrm{m}^{2}$ \\
\hline Široki Brijeg & $15 € / \mathrm{m}^{2}$ & $800 € / \mathrm{m}^{2}$ \\
\hline Međugorje & $65 € / \mathrm{m}^{2}$ & $1700 € / \mathrm{m}^{2}$ \\
\hline
\end{tabular}

Source: www.nekretnine.hr

\section{Social dimension of tourism development in Međugorje}

Apart from the negative and devastating impact that tourism has on the environment of Međugorje, there is also a positive socio-cultural impact on the population.

An increasing number of young people stay on in the village because of tourism; they are educatingto work in tourism (both in high schools and universities), and learn foreign languages. However, such uncontrolled tourism causes a loss of moral values, religious feelings of the local population change due to the rapid accumulation of 
wealth, so do cultural habits; a new system of values is established, old traditions are replaced, etc.

Table 6: List of important dates for the testimony of faith in Međugorje

\begin{tabular}{|c|c|}
\hline 1. & $\begin{array}{l}18^{\text {th }} \text { March: Our Lady appears to Mirjana on her birthday - the most frequent } \\
\text { guests are Italians }\end{array}$ \\
\hline 2. & $\begin{array}{l}2^{\text {nd }}-6^{\text {th }} \text { March: Seminar held for organizers and tourist guides from all over the } \\
\text { world }\end{array}$ \\
\hline 3. & $25^{\text {th }}$ March: The Annunciation of Our Lady - a feast in Međugorje \\
\hline 4. & $4^{\text {th }}$ June: Corpus Christi, Brešančevo \\
\hline 5. & $12^{\text {th }}$ to $14^{\text {th }}$ May: Seminar for married couples - renewal vows \\
\hline 6. & $13^{\text {th }}$ to $16^{\text {th }}$ May: Seminar for physicians \\
\hline 7. & $24^{\text {th }}$ June: Peace March from Humac in Međugorje - hiking \\
\hline 8. & $25^{\text {th }}$ June: The visionary Ivanka has special apparitions \\
\hline 9. & $25^{\text {th }}$ June: The day of the Apparition of the Virgin Mary \\
\hline 10 . & $\begin{array}{l}6^{\text {th }}-11^{\text {th }} \text { July: Seminar for priests - super } 500 \text { priests Spiritual Renewal - } \\
\text { making contacts }\end{array}$ \\
\hline 11. & $25^{\text {th }}$ July: St. James the patron of the parish of Međugorje James \\
\hline 12. & $1^{\text {st }}-6^{\text {th }}$ August: International youth festival Međugorje \\
\hline 13. & $5^{\text {th }}$ August: Our Lady of the Snows \\
\hline 14. & $15^{\text {th }}$ August: the religious feast of the Assumption of Mary \\
\hline 15. & $\begin{array}{l}7^{\text {th }} \text { September: the religious feast of the birth of Virgin Mary - the Holy Mass } \\
\text { on Križevac }\end{array}$ \\
\hline 16. & $\begin{array}{l}24^{\text {th }} \text { November: Anniversary of Father Slavko Barbarić - he is the founder of } \\
\text { Mother's Village in Bijakovići, which always hosts around } 60 \text { children; also, } \\
\text { he founded Cenacolo Community, two houses - one for the rehabilitation of } \\
\text { men, the other for women. }\end{array}$ \\
\hline 17. & Every $2^{\text {nd }}$ day in the month, Virgin Mary appears to the seer Mirjana \\
\hline 18. & At Christmas on $25^{\text {th }}$ December the virgin Mary appears to Jakov Čolo \\
\hline 19. & $2^{\text {nd }}$ November: All Saints' Day \\
\hline 20. & $\begin{array}{l}26^{\text {th }} \text { December: St. Stephen the first martyr, is particularly celebrated in } \\
\text { Međugorje }\end{array}$ \\
\hline 21. & $27^{\text {th }}$ December: Holy Family - a grand feast in Međugorje \\
\hline 22. & Every day the seer Vicka - in Krehin Gradac, Vicka and Ivan and Marija \\
\hline 23. & $\begin{array}{l}\text { Every } 25^{\text {th }} \text { day in the month the seer Marija Pavlović Luneti has apparitions, } \\
\text { the Virgin Mary sends messages through her. }\end{array}$ \\
\hline
\end{tabular}

Research has shown that the number of important dates for the testimony of faith, when pilgrims more often than usual come to Međugorje compared to 1981 has increased two hundred times (table 6). Even a superficial glance at these important dates indicates the violation of cultural traditions of the region. In the past, the village acknowledged the 
patron Saint James day, the Apparition and the Assumption. Today, there are 19 important days of the year, beside the apparitions of those who were the first seers. Some of them reportedly have daily apparitions, others every $2^{\text {nd }}$ day of the month, others on the $25^{\text {th }}$ of every month.

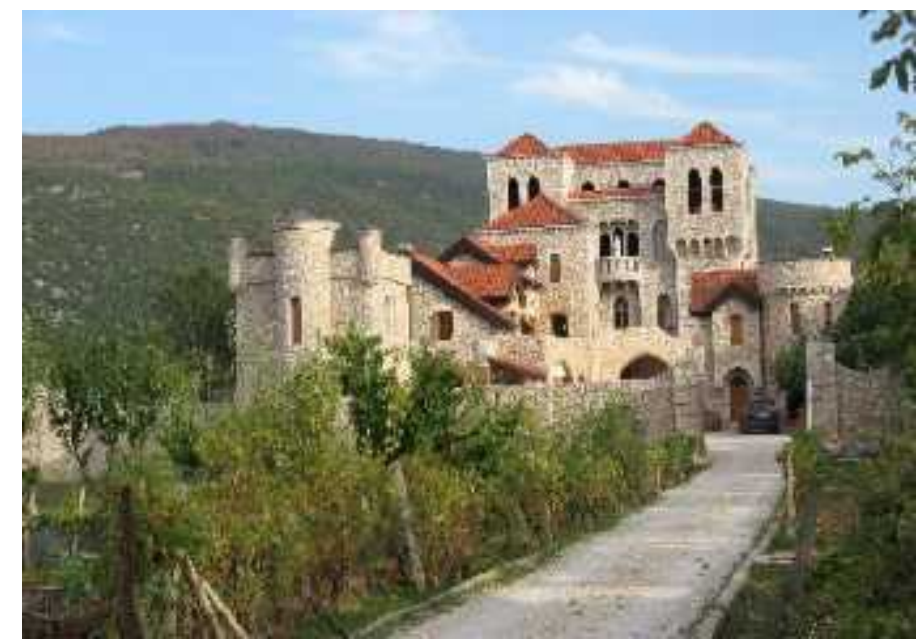

Figure 12: Unsuitable architecture in the local urban ambience of Međugorje - Nancy and Patrick's castle

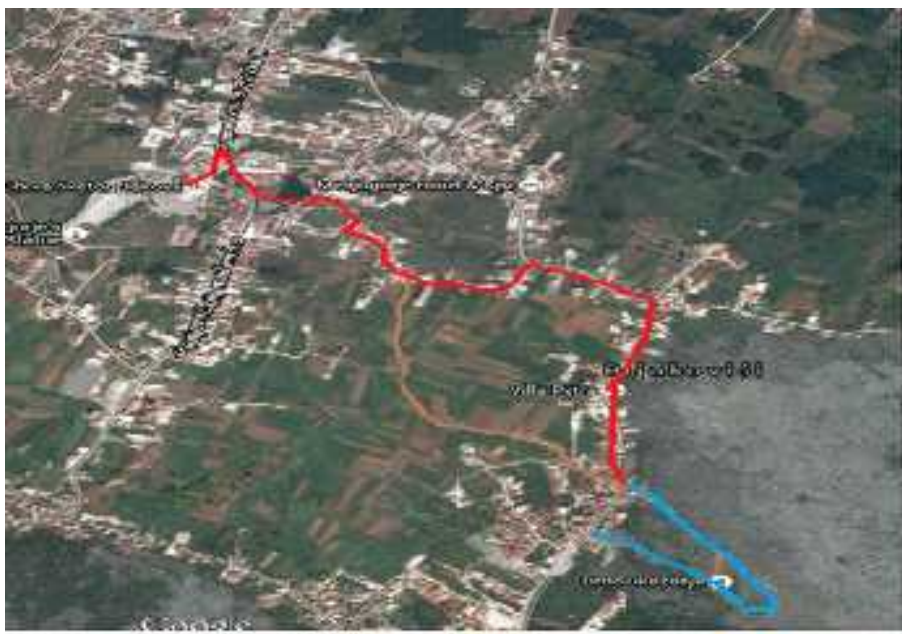

Figure 13: Pilgrims walk to with cars and buses in a single lane. The second route, in the drawing to the left, in brown, is a hiking trail through the vineyards the apparition site along

Even though religious people are not common tourists as they are motivated by their faith and hope, they do bring incredibly large financial benefits. Their demands concerning additional tourist privileges are modest and are reduced to the satisfaction of form: holy mass in the language of the pilgrims, a reception by one of the visionaries, simple accommodation and three meals a day of standard European kitchen. The 
Međugorje region has no traditional individuality, no old way of life, creative tourism is non-existent. The tourist market in the destination of religious tourism in not organized. It happened spontaneously and by chance. There is no unique market with comprehensive marketing activities, especially no joint promotion of religious tourism. There is no vision, mission, or goals of the religious tourism development. No new products are being offered to tourists. The offer is becoming poorer and less inventive. There are no attractions or cultural facilities built. There is no concept of long-term development and no management strategy. The cooperation between the public and private sectors is insufficient.

The economic aspect of religious tourism in Međugorje is certainly evident in the wider region of the village, in the change of the landscape, density of dwellings, in the change of land use, in urban villas, but only in a narrow aspect.

These achievements fail, for example, to provide financial support for public consumption of the Čitluk Municipality in which Međugorje is located. Each year Čitluk almost goes bankrupt, there is no money for public investment, no new roads, no modernization of roads or electric networks, and no sewage. Further range of the economic benefits of Međugorje is unknown. Vegetables and fruits are imported from the EU. And Herzegovina had once exported to Europe the first cherries of the season; it had supplied Dalmatia and Bosnia with its vegetables. Guests from Međugorje come to Mostar on a two hour trip, pass an hour visiting the waterfall Kravica where they spend money just for a few souvenirs. They go back to their hosts for lunch. Domestic producers of meat, milk and cheese have no chance of coming into the Međugorje market and there is no will to establish a cooperative collaboration for the production of vegetables, fruit, jams or juices. Data from the parish office in Međugorje shows that they annually use about 2 million sacred hosts, which might indicate the approximate number of pilgrims. Although such number of visitors indicates the possibility of employing a far greater number of participants in the realization of tourist visits, local economy is not developed. A good example is the terrycloth factory 'Fratea' in Čitluk; before the war it manufactured high quality towels, terrycloth blankets etc. but has been shut down.

\section{CONCLUSION}

Until 1980 the area of Brotnjo with Međugorje was a typical emigration area. Due to its weak geographical potential, its inhabitants left to larger industrial centres like Mostar, Sarajevo and Zagreb, and also to Western Europe. With the Marian apparition in 1981, emigration ceased, even immigration started, both domestic and foreign. It is mostly comprised of the Irish, big Catholic believers, who open hotels and travel agencies sometimes together with the local people, but also on their own. Agriculture ceased to be the dominant occupation; today it is almost entirely neglected. Vineyards and wine cellars prosper. They use sophisticated technology, produce quality wines and employ a 
small workforce. They represent a secondary employment, which is in the function of tourism. The population is entirely devoted to tourism and trade with the percentage of agricultural population in total - from the pre-war almost $50 \%$ - decreased to only $1 \%$ (Federal Statistics Institute, 2015).

Urban development in Međugorje took place impetuously. The infrastructure didn't accompany the development. Today, the roads are narrow, pedestrian pavements nonexistent, there is no sewage system, the electric supply is insufficient etc. Urban transport as communication with the main urban centre in Herzegovina runs only two times a day. The process of urbanization is a prerequisite for an organised city way of life, it is the basis for the development of social life in general. Among other things, it implies a sewage. It is not yet an element of urbanization in Međugorje, so in addition to illegal civil constructions and bad roads, it present even greater threat for the environment.

A special cultural, social and economic problem in Međugorje is its infrastructure. The region which annually receives at least a million visitors has no sewerage. Waste water from bathrooms and toilets, and also from laundries end in karst area of the Brotnjo plateau on which Međugorje is located. It is tectonically cracked, crisscrossed with faults, sinkholes and karst valleys, which form a whole system of underground connected cracks with the waste water usually ending in karst springs along the rim of the Brotnjo plateau or into the Adriatic Sea. Due to poor environmental awareness, the inhabitants often throw mercury into their septic tanks with the aim to expand the cracks in the ground enabling faster drainage of waste content into the karst underground. What are the immediate consequences, or the future ones is difficult to perceive. The fact remains that compared to the pre-war data, prevalence of lung cancer has increased 400 times in the Neretva River valley.

Pilgrimage tourism is specific because it is reflected in the fact that tourists return to the place of pilgrimage. According to Madžar (2010), $62 \%$ of pilgrims have visited Međugorje more than three times. They do not experience problems with a non-existent sewage. Organized chaos in spatial planning, economic development and political decision-making are images that make Međugorje today. However, tourists who come to Međugorje today are better educated, more demanding, more selective and therefore Međugorje as a brand has to change its current trend of chaos.

The modern global society is fast, concentrated, creative, and Međugorje has to align its services, its culture and heritage with the marketing standards and thus create its own development strategy. Although a brand of religious tourism, Međugorje exists in the world of ICT, intellectual capital and knowledge which must be built in the tourist development of this destination. 


\section{REFERENCES}

1. Belaj, M., 2011: Međugorje kao proces, Specijalizacija iskustava i stvaranje “mjesta”. Mjesto, nemjesto: interdisciplinarna promišljanja prostora i kulture.

2. Collins, E.G.C., Devanna, M.A.: Izazovi menadžmenta u XXI stoljeću, MATE, Zagreb, 2002.

3. Krešić, D., Mikulić, J., Miličević, K.2012.: The Factor Structure of Tourist Satisfaction at Pilgrimage Destinations: the Case of Medjugorje. International journal of tourism research.

4. Leutar, I., Neuhold, L., Leutar, Z. 2007: Obilježja hodočasnika u Međugorju motivi i značenje hodočašća. Bogoslovska smotra 77(1), 217-243.

5. Madžar, I.2010: Osnovne značajke vjerskog turizma u Međugorju. Acta Geographica Croatica, Vol. 36 99.-117.

6. Osmanković,J., N. Babić, Hošo, J. 2007.: Hodočašća kao čimbenik lokalnoga $i$ regionalnog razvoja - primjer Bosne i Hercegovine. Acta Turistica, Vol.19 No.2., 182- 195.

7. Pourtaheri, K. Rahmani \& H. Ahmadi, 2012.: Impacts of Religious and Pilgrimage Tourism in Rural Areas: The Case of Iran. Journal of Geography and Geology; Vol. 4, No. 3.

8. Vijayanand, S., 2012.: Socio-economic impacts in pilgrimage tourism, Zenith International Journal of Multidisciplinary Research,Vol.2 Issue 1, 329- 343.

9. www.booking.com

10. www.nekretnine.com

11. www.medjugorje.com 